\title{
Mosaic epidermolytic ichthyosis - Case report ${ }^{*}$
}

\author{
Ictiose epidermolítica em mosaico - Relato de caso
}

\author{
Marcela Sena Teixeira Mendes ${ }^{1}$ \\ Thaissa Araújo Aquino ${ }^{1}$ \\ Antonio de Padua Lima ${ }^{3}$
}

\author{
Samara Silva Kouzak ${ }^{1}$ \\ Gustavo Henrique Soares Takano²
}

DOI: $h$ ttp://dx.doi.org/10.1590/abd1806-4841.20132203

\begin{abstract}
Epidermolytic ichthyosis is a rare autosomal dominant disease that manifests at birth with fragile blisters and erosions that evolve into hyperkeratotic lesions associated or not with erythroderma. When the disease is associated with a mutation in cytokeratin 1, it may be related to hyperkeratosis of palms and soles, but this is not usually found when cytokeratin 10 is mutated. The disease can present in a mosaic form, due to post zygotic mutation of the gene involved, constituting an individual formed by two populations of genetically distinct cells - one carrier of the mutation and the other without it. We report a case of mosaic epidermolytic ichthyosis diagnosed in a female patient.
\end{abstract}

Keywords: Hyperkeratosis, epidermolytic; Ichthyosis; Mosaicism

Resumo: A ictiose epidermolítica é doença autossômica dominante rara que se manifesta ao nascer com bolhas frágeis e erosões que evoluem para lesões hiperceratóticas associadas ou não a eritrodermia. Quando associada à mutação da citoqueratina 1 pode estar relacionada à hiperceratose palmoplantar, porém quando o defeito está relacionado à mutação da citoqueratina 10, este achado não é comumente encontrado. A doença pode ainda se manifestar em forma de mosaicismo somático, devido a mutação pós zigótica do gene envolvido, formando um indivíduo com duas populações de células geneticamente distintas, uma com a mutação e outra sem a mutação. Relata-se um caso de ictiose epidermolítica em mosaico em paciente do sexo feminino.

Palavras-chave: Hiperceratose epidermolítica; Ictiose; Mosaicismo

\section{INTRODUCTION}

Epidermolytic ichthyosis, previously known as epidermolytic hyperkeratosis, is an autosomal dominant disorder with an incidence of 1:100000 to 1:400000. ${ }^{1-4}$ It equally affects both sexes. ${ }^{3}$ The first manifestations of the disease occur at birth, in the form of multiple erosions that subsequently originate hyperkeratotic lesions. ${ }^{5}$ Epidermolytic ichthyosis may also be due to post-zygotic somatic mutation, manifesting as mosaicism, with areas of healthy skin interspaced with areas of lesion that often follow Blaschko's lines. ${ }^{1,4,6}$ The mosaic form of epidermolytic ichthyosis is also known as epidermolytic nevus because of its similarity to linear epidermal nevus. ${ }^{1}$ The objective of this study is to report a case of mosaic epidermolytic ichthyosis in a female patient.

\section{CASE REPORT}

Female patient, 37 years old, has presented with blisters and erosions in her axilla, groin, gluteal region and left flank since she was 3 months old. Lesions later became hyperkeratotic and verrucous. The patient has a healthy son without similar lesions. She reported no previous diseases, use of medication, previous hospitalizations, surgeries, drug allergies or similar diseases in the family.

On examination, hyperchromic plaques with verrucous papules were observed in her axilla, groin and gluteal region, following Blaschko's lines. Palmoplantar hyperkeratosis (Figures 1-5) was also seen. All lesions were located in her left hemibody.

The patient underwent a biopsy procedure. Histopathologic examination revealed an epidermis

\footnotetext{
Received on 15.10.2012.

Approved by the Advisory Board and accepted for publication on 05.11.2012.

* Work conducted at the University Hospital of Brasilia - University of Brasília (HUB-UnB) - Brasilia (DF), Brazil.

Conflict of interest: None

Financial funding: None

Resident of Dermatology, University Hospital of Brasilia - University of Brasília (HUB-UnB) - Brasilia (DF), Brazil.

Pathologist - Preceptor of the residency program in Pathology, University Hospital of Brasilia - University of Brasília (HUB-UnB) - Brasilia (DF), Brazil.

Dermatologist - Preceptor of the residency program in Dermatology, University Hospital of Brasilia - University of Brasília (HUB-UnB) - Brasilia (DF), Brazil.

(C2013 by Anais Brasileiros de Dermatologia
} 
with extensive foci of hyperkeratosis and parakeratosis, under which there were hypergranulosis and vacuolar degeneration of the granular layer and the upper layers of the stratum spinosum (Figure 6). The pattern described confirmed the clinical hypothesis of epidermolytic ichthyosis.

The patient was treated with topical retinoic acid with improvement of the lesions on the trunk and persistence of the other lesions.

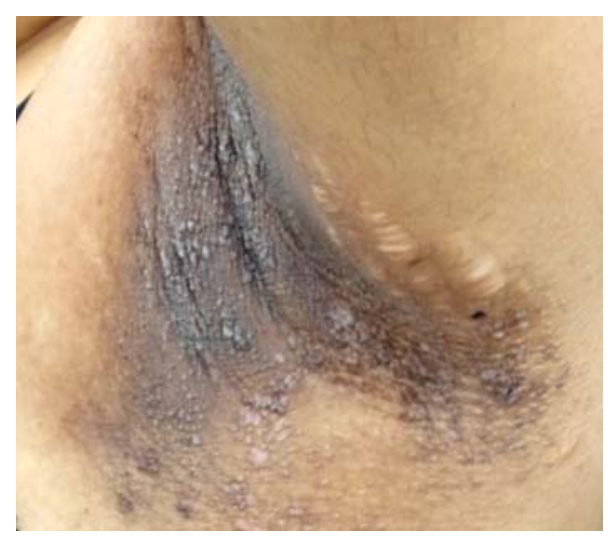

FIGURE 1: hyperkeratotic papules in the left axillary region. Lesions are located mainly on areas of friction, usually in the folds

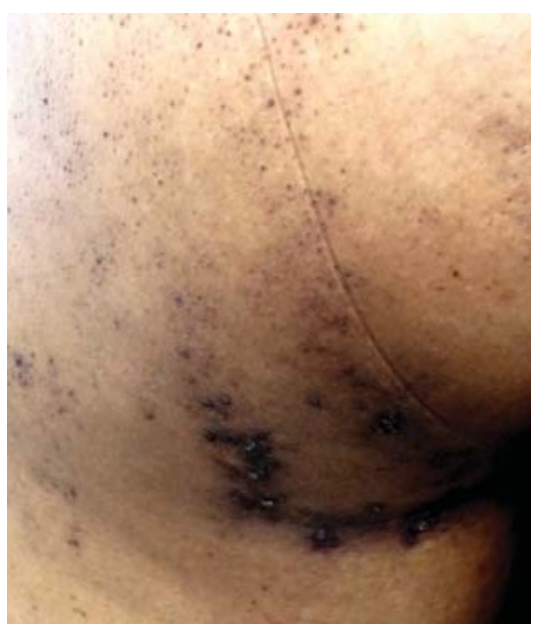

FIGURE 2: hyperchromic hyperkeratotic papules following an upward linear pattern in the left gluteal region

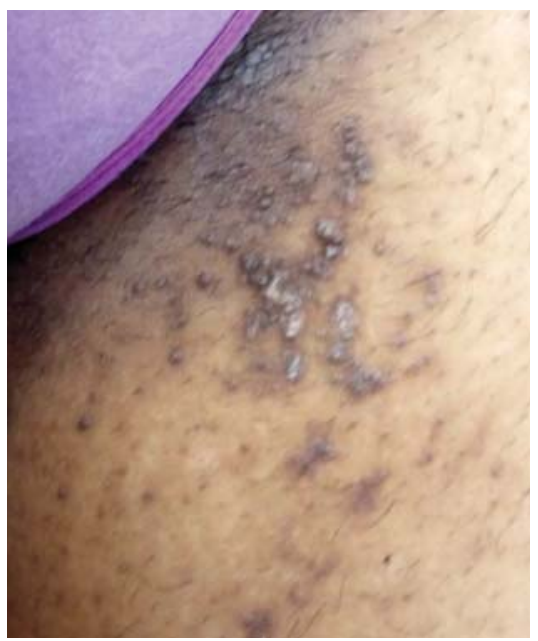

Figure 3: hyperchromic hyperkeratotic papules in the proximal left thigh, showing a Chinese character aspect

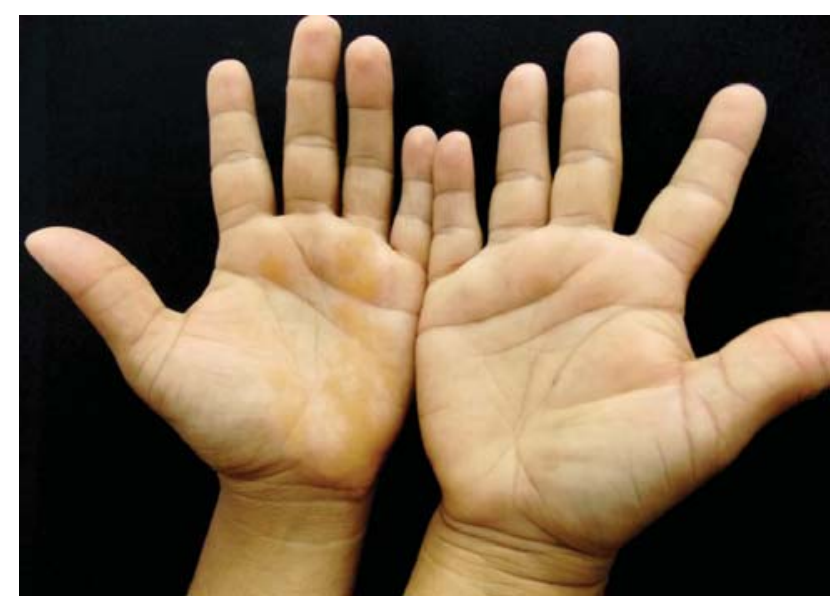

FIGURE 4: left palmar hyperkeratosis. Note the exclusive involvement of the left hemisphere

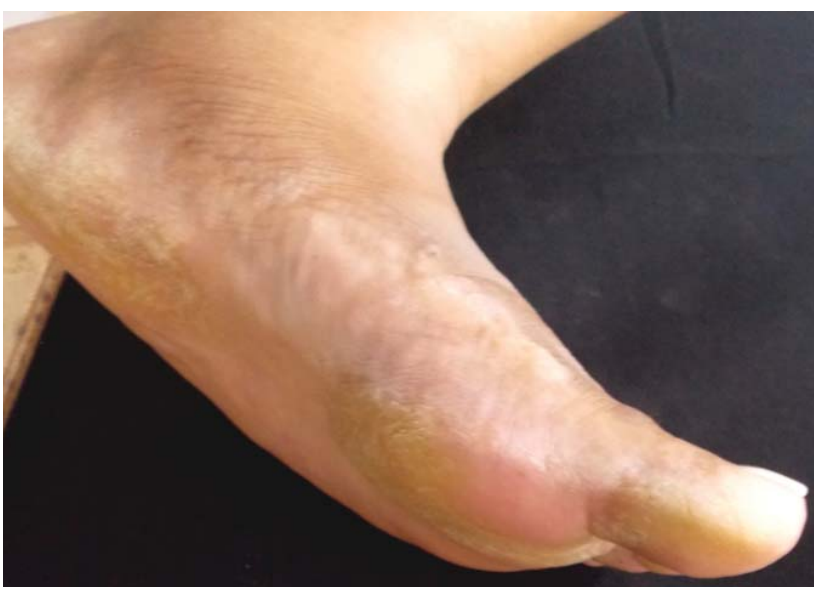

FIGURE 5: left plantar hyperkeratosis. This finding is commonly associated with mutation of cytokeratin 1

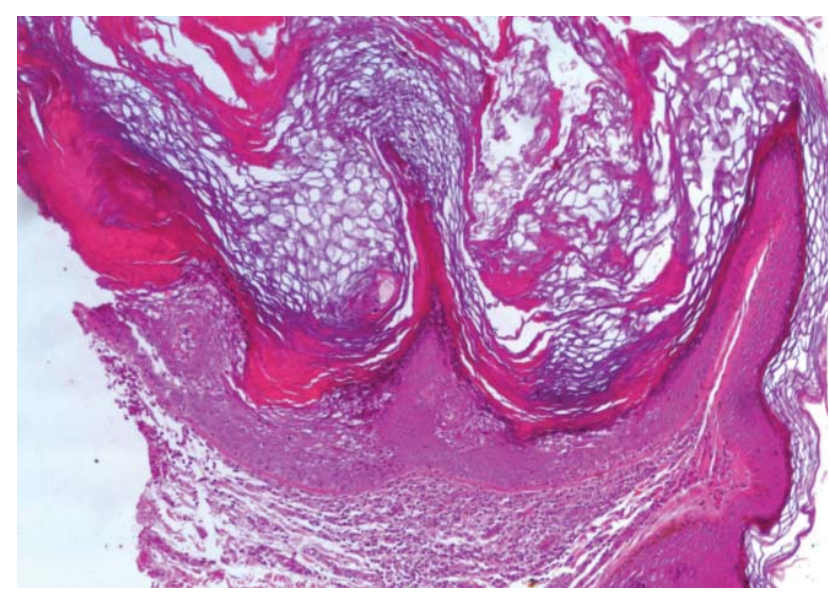

FIGURE 6: epidermolytic hyperkeratosis: parakeratosis, hypergranulosis and vacuolar degeneration of the granular and spinous layer. Hematoxylin and eosin staining 


\section{DISCUSSION}

Epidermolytic ichthyosis is a disorder of keratinization (type III), inherited as an autosomal dominant trait with complete penetrance, although reports of recessive inheritance have been described. ${ }^{1,3,7-10}$ The disease was previously known as epidermolytic hyperkeratosis or congenital bullous ichthyosiform erythroderma of Brocq. ${ }^{5,9}$ The new nomenclature was suggested in a 2009 expert consensus document for specificity reasons, as epidermolytic hyperkeratosis is a histopathological term that can also be used to describe other diseases. ${ }^{1,4,10}$

The incidence of epidermolytic ichthyosis varies from 1:100000 to 1:400000 individuals. ${ }^{2,3,4}$ The disease is due to mutations in cytokeratin 1 (KRT1) and 10 (KRT10), whose genes are located on chromosomes 12q13.3 and 17q21.2, Cytokeratins form a structural network within the cell, providing support and a three-dimensional organization to keratinocytes. In the basal layer, keratinocytes express cytokeratins 5 and 14, while in the spinous and granular layers they express cytokeratins 1 and 10. Thus, mutations in cytokeratins 1 and/or 10 weaken the keratinocytes of the upper layers of the epidermis, which acquire the vacuolar appearance typical of this disease.

Epidermolytic ichthyosis was classified into six forms of which three are associated with palmoplantar hyperkeratosis., ${ }^{910}$ The presence of palmoplantar hyperkeratosis, as in the case described, is linked to a mutation in cytokeratin 1. However, mutation in cytokeratin 10 has also been associated with this form of the disease in some reports.. In these forms, cytokeratin 1 may associate with cytokeratin 9 to replace the mutated cytokeratin 10.4

The first manifestations of the disease are fragile blisters and erosions that appear at birth and that soon give way to hyperkeratotic lesions with or without erythroderma. ${ }^{5}$ The lesions tend to be located in skin folds, where there is more friction. ${ }^{3}$ In the mosaic form, there may be bilateral involvement or just one side of the body may be affected, and it may follow Blaschko's lines, as in the case described. ${ }^{1,46}$

The mosaic form of epidermolytic ichthyosis, epidermolytic nevus, is derived from post-zygotic somatic de novo mutation, with no relatives previously affected. Spontaneous mutations are responsible for $50 \%$ of all cases., ${ }^{5,10}$ Two types of mosaicism may be involved: type 1 mosaicism, in which, during embryonic development, one allele of the gene involved is mutated, causing the disease in mosaic form; type 2 mosaicism, which occurs in heterozygous carriers of the disease that have lost the other normal allele due to standard post-zygotic mutation during embryonic development (loss of heterozygosity). This event results in more severe and earlier manifestations of the disease in a mosaic pattern, in individuals with a lighter, more diffuse presentation of the disease. In the case reported, the disease is present only in the mosaic form, establishing type 1 mosaicism.

In epidermolytic nevus, if there is involvement of the gonads, there can be transmission of the defective gene to the offspring, who, in this case, will present with generalized epidermolytic ichthyosis. ${ }^{7}$

Diagnosis may be aided by histopathology, which shows perinuclear vacuolization of the keratinocytes of the stratum granulosum and stratum corneum; reticulated appearance of the epidermis caused by keratinocytes with ill-defined limits, an increased number of basophilic bodies with a keratohyalin appearance, eosinophilic bodies with a trychohyaline appearance and compact hyperkeratosis of the stratum corneum. ${ }^{3,4,6}$ Continuous involvement of the epidermis is commonly found in fullblown forms of epidermolytic ichthyosis, while focal involvement can be found in the mosaic forms of the disease. ${ }^{10}$

The differential diagnosis of epidermolytic ichthyosis can be made with other forms of ichthyosis, such as superficial epidermolytic ichthyosis or ichthyosis bullosa of Siemens. In cases of mosaicism, the major differential diagnosis is done with linear epidermal nevus. ${ }^{3}$

The treatment of epidermolytic ichthyosis, as well as that of other forms of ichthyosis, is done with the use of emollients, keratolytic agents, topical retinoids, topical vitamin $\mathrm{D}$ analogues and oral retinoids. ${ }^{6,9}$ In the case reported, there was a partial response to topical therapy. As the patient intended to get pregnant again, the use of acitretin was not considered.

The recognition of this disease becomes important considering its differential diagnoses. Once the disease is diagnosed, affected parents can receive genetic counseling, guidelines about the expected course of the disease, and more severe forms of inherited ichthyosis can be excluded. Diagnosis can only be established based on prior knowledge of the disease, and this is what motivates the publication of this case report. $\square$ 


\section{REFERENCES}

1. Oji V, Tadini G, Akiyama M, Blanchet Bardon C, Bodemer C, Bourrat E, et al. Revised nomenclature and classification of inherited ichthyoses: results of the First Ichthyosis Consensus Conference in Sorèze 2009. J Am Acad Dermatol. 2010;63:607-41.

2. el-Khateeb EA. Bullous congenital ichthyosiform erythroderma associated with hypocalcemic vitamin D-resistant rickets. Pediatr Dermatol. 2008;25:279-82.

3. Lacz NL, Schwartz RA, Kihiczak G. Epidermolytic hyperkeratosis: a keratin 1 or 10 mutational event. Int J Dermatol. 2005;44:1-6.

4. Sousa PF, Salas IR, Crisóstomo MCC, Oliveira EF, Azulay RD, Kac BK. Mosaic Epidermolytic Hyperkeratosis. An Bras Dermatol. 2003;78:477-81.

5. Nassif PW, Nakandakari S, Fogagnolo L, Contin LA, Alves CJ. Epidermolytic hyperkeratosis: a follow-up of 23 years of use of systemic retinoids. An Bras Dermatol. 2011;86:S72-5.

6. Umekoji A, Fukai K, Ishii M. A case of mosaic-type bullous congenital ichthyosiform erythroderma successfully treated with topical maxacalcitol, a vitamin D3 analogue. Clin Exp Dermatol. 2008;33:501-2.

7. Akhyani M, Kiavash K, Kamyab K. Bullous ichthyosiform erythroderma in a child born to a parent with systematized linear epidermolytic hyperkeratosis. Int $\mathrm{J}$ Dermatol. 2009;48:215-7.

8. Bergman R, Khamaysi Z, Sprecher E. A unique pattern of dyskeratosis characterizes epidermolytic hyperkeratosis and epidermolytic palmoplantar keratoderma. Am J Dermatopathol. 2008;30:101-5.

9. Morais P, Mota A, Baudrier T, Lopes JM, Cerqueira R, Tavares P, et al. Epidermolytic hyperkeratosis with palmoplantar keratoderma in a patient with KRT10 mutation. Eur J Dermatol. 2009;19:333-6.

10. Ross R, DiGiovanna JJ, Capaldi L, Argenyi Z, Fleckman P, Robinson-Bostom L. Histopathologic characterization of epidermolytic hyperkeratosis: a systematic review of histology from the National Registry for Ichthyosis and Related Skin Disorders. J Am Acad Dermatol. 2008;59:86-90.

\author{
MAILING ADDRESS: \\ Marcela Sena Teixeira Mendes \\ SGAN 605 - Avenida L2 Norte \\ 70910-900 - Brasília - DF \\ Brazil \\ E-mail: marcela_sena@yahoo.com.br
}

How to cite this article: Mendes MST Kouzak SS, Aquino TA, Takano GHS, Lima AP. Mosaic epidermolytic ichthyosis: A case report. An Bras Dermatol.2013; 88 (6 Suppl 1):S116-9. 